\title{
Removal of Phenol from Aqueous Solutions by Polymeric Composites Containing Ni and Co Particles
}

\author{
Simone Simplício, Luiz Cláudio de Santa Maria, Marcos Antônio da Silva Costa \\ Instituto de Química, Universidade do Estado do Rio de Janeiro - UERJ
}

Elizabete Fernandes Lucas, Yure Gomes de Carvalho Queirós, Luiz Rodrigo da Silva Marques
Instituto de Macromoléculas Professora Eloísa Mano, Universidade Federal do Rio de Janeiro - UFRJ

Luciana da Cunha Costa

Centro Setorial de Ciências Biológicas e da Saúde, Centro Universitário Estadual da Zona Oeste - UEZO

\author{
Wang Shu Hui \\ Departamento de Engenharia Metalúrgica e Materiais, \\ Escola Politécnica, Universidade de São Paulo - USP \\ Manoel Ribeiro Silva
Departamento de Física e Química, Instituto de Ciências, Universidade Federal de Itajubá - UNIFEI
}

\begin{abstract}
Magnetic composites have a wide range of potential technological applications; however the evaluation of this material for extraction of phenolic compounds has not been sufficiently studied. Due to its high toxicity and solubility the removal of phenolic compounds from the aquatic environments has critical importance. In this work polymeric composites were prepared by anchoring $\mathrm{Ni}$ and Co particles on sulfonatedpoly(styrene-co-divinylbenzene) PS-DVB. The PS-DVB beads were synthesized by suspension polymerization and reacted with acetyl sulfate, aiming to obtain sulfonated copolymers. All materials were capable of removing phenol from aqueous solutions. The phenol adsorption kinetics was influenced by the polymer porosity and swelling capacity in water. The composite derivative of the more porous copolymer impregnated with nickel (C1SNi) was the most efficient in phenol removal, with the sorption equilibrium being established more rapidly than for the other composites. The pseudo second-order model was more adequate to describe the phenol adsorption process for the composite C1SNi. The Langmuir model describes successfully the phenol removal by this composite.
\end{abstract}

Keywords: Adsorption, composites, porous materials, magnetic composites, phenol.

\section{Introduction}

Phenolic compounds are present in wastewaters from the petroleum, pulp and paper, pesticide, dye and chemical industries. Phenol produces harmful effects on human and animal health and aquatic ecosystems even at low concentrations. Due to its acute toxicity and good solubility and potentially carcinogenic effect, phenolic compounds are considered highpriority contaminants ${ }^{[1,2]}$. Several methods have been proposed for treating wastewater containing phenol and its derivatives. These methods include solvent extraction, activated carbon filtration, dialysis, microbial degradation, oxidation, membrane filtration and polymer adsorption. In relation to traditional adsorbents such as silica and activated carbon, polymeric resins are a more attractive alternative, due to the possibility of preparing tailor-made materials by controlling the synthesis conditions $^{[1,3,4]}$.

Polymeric resins based on divinylbenzene copolymers such as poly (N-vinylpyrrolidonedivinylbenzene, poly (styrene-divinylbenzene) modified with amine, hypercrosslinked polymeric resin (MN200), Amberlite XAD-4, crosslinked poly-4-vinylpyridine and poly(methylmethacrylate-divinylbenzene) have been evaluated for removing phenolic compounds from wastewater ${ }^{[2,5-9]}$. Although magnetic composite materials have a wide range of potential technological applications, such as water treatment, cell labeling, cell separation, enzyme immunoassaying and drug targeting, the evaluation of this type of material for extraction of phenolic compounds has not been sufficiently studied $^{[10-14]}$. In our last work, we verified that it is possible to prepare micrometer-sized magnetic particles $\left(\mathrm{NiFe}_{2} \mathrm{O}_{4}, \mathrm{CuFe}_{2} \mathrm{O}_{4}, \mathrm{CoFe}_{2} \mathrm{O}_{4}\right.$ and $\left.\mathrm{MnFe}_{2} \mathrm{O}_{4}\right)$, hosted on commercial Sty-DVB copolymers ${ }^{[10]}$.

The aim of this work was to develop polymeric resins based on styrene-divinylbenzene copolymers modified by sulfonation reaction anchored with $\mathrm{Ni}$ and $\mathrm{Co}$. These materials were characterized and their performance in removing phenol from aqueous solutions was evaluated.

\section{Experimental}

Materials

Commercial styrene (Sty) and divinylbenzene (DVB) were donated by Nitriflex Indústria e Comércio S.A. (Rio de Janeiro, Brazil) and were used as

Corresponding author: Luiz Cláudio de Santa Maria, Instituto de Química, Universidade do Estado do Rio de Janeiro - UERJ,

Rua São Francisco Xavier, 524, Maracanã, CEP 20550-900, Rio de Janeiro, RJ, Brasil, e-mail: Icsantamaria@terra.com.br 
received. 2,2-azo-bis-(2-methylbutanonitrile-AIBN) and 2-hydroxyethylcellulose were donated by Metacril (Rio de Janeiro, Brazil) and Union Carbide (New Jersey, USA), respectively, and also used as received. The diluents n-heptane, toluene and others reagents were purchased from Vetec Química Fina Ltda. (Rio de Janeiro, Brazil) and used as received.

\section{Preparation of Sty-DVB copolymers}

The Sty-DVB copolymers were synthesized by aqueous suspension polymerization, as described previously ${ }^{[10-14]}$. The aqueous phase was constituted of $450 \mathrm{~cm}^{3}$ of water, $\mathrm{NaCl}(18.0 \mathrm{~g})$, gelatin $(0.9 \mathrm{~g})$ and 2-hydroxiethylcellulose $(0.4 \mathrm{~g})$. The organic phase was composed of Sty $\left(57 \mathrm{~cm}^{3}\right)$, DVB $\left(17 \mathrm{~cm}^{3}\right)$, AIBN $(1.2 \mathrm{~g})$ and a diluent mixture composed of three different n-heptane/toluene ratios (90:10, 60:40 and 00:100 v/v in relation to total volume of diluent mixture). The polymerization reaction was carried out under reflux at $70{ }^{\circ} \mathrm{C}$, for $24 \mathrm{~h}$, at constant stirring of $400 \mathrm{rpm}$. The beads obtained were washed with warm water $\left(70^{\circ} \mathrm{C}, 6\right.$ portions of $\left.500 \mathrm{~cm}^{3}\right)$ and acetone $\left(250 \mathrm{~cm}^{3}\right)$ in a Soxhlet extractor (reflux temperature, $24 \mathrm{~h}$ ) and dried at $60{ }^{\circ} \mathrm{C}$ for $24 \mathrm{~h}$.

\section{Sulfonation of the Sty-DVB copolymers}

The Sty-DVB copolymers were sulfonated with acetyl sulfate as previously described ${ }^{[15]}$. The acetyl sulfate was prepared in advance by mixing concentrated sulfuric acid $\left(4 \mathrm{~cm}^{3}\right)$, acetic anhydride $\left(10 \mathrm{~cm}^{3}\right)$ and 1,2-dichloroethane $\left(15 \mathrm{~cm}^{3}\right)$ in an ice bath. The Sty-DVB beads, previously swollen in 1,2-dichloroethane by $24 \mathrm{~h}$, were reacted with acetyl sulfate for $24 \mathrm{~h}$ at $90{ }^{\circ} \mathrm{C}$. The sulfonated beads were then washed with ice water $\left(6\right.$ portions of $\left.500 \mathrm{~cm}^{3}\right)$ and acetone $\left(250 \mathrm{~cm}^{3}\right.$ ) in a Soxhlet extractor (reflux temperature, $24 \mathrm{~h}$ ) and dried at $60{ }^{\circ} \mathrm{C}$ for $24 \mathrm{~h}$.

\section{Synthesis of polymeric composites}

Sulfonic resins $(0.5 \mathrm{~g})$ were immersed in aqueous solutions containing salts of $\mathrm{Ni}^{2+}$ and $\mathrm{Co}^{2+}\left(0.25 \mathrm{~mol} \mathrm{~L}^{-1}\right)$ $\left(\mathrm{NiCl}_{2} \cdot 6 \mathrm{H}_{2} \mathrm{O}\right.$ and $\left.\mathrm{CoCl}_{2} \cdot 6 \mathrm{H}_{2} \mathrm{O}\right)$, respectively, for $24 \mathrm{~h}$. After this the beads were washed with deionized water and kept in contact with an aqueous suspension of $0.5 \%$ of polyvinylpyrrolidone (PVP) $\left(10 \mathrm{~cm}^{3}\right)$ in a $250 \mathrm{~mL}$ three-necked round bottomed reactor flask equipped with a reflux condenser. Hydrazine sulfate (20\%) and saturated $\mathrm{NaOH}$ solutions were previously prepared and transfered to the flask already containing the sulphonic resin. The suspension system was warmed at $70{ }^{\circ} \mathrm{C}$ for $24 \mathrm{~h}$ to produce nickel and cobalt particles. Finally, the beads were thoroughly washed with deionized water ( 3 portions of $\left.250 \mathrm{~cm}^{3}\right)$ and acetone $\left(250 \mathrm{~cm}^{3}\right)$ and dried at $60{ }^{\circ} \mathrm{C}$ by $48 \mathrm{~h}^{[10-12]}$.

\section{Characterization of the polymers}

The Sty-DVB copolymers were characterized by determining the apparent density ${ }^{[10-12]}$, swelling degree in 1,2-dichloroethane ${ }^{[10-12]}$, surface area and pore volume distribution by nitrogen adsorption followed the BET and BJH methods, respectively (Micromeritcs ASAP 2020 apparatus), and by scanning electron microscopy (Philips XL-30, $20 \mathrm{keV}$, gold coating).

The modification reactions of the Sty-DVB copolymers were monitored by FTIR spectrometry (Perkin-Elmer, Spectrum One spectrometer, 4 scans and $4 \mathrm{~cm}^{-1}$ resolution, by pressed disk with $\mathrm{KBr}$ ) and energy dispersive X-ray analysis (EDS) coupled to a SEM. The ion exchange capacity of the sulfonic resins was determined by acid-base titration ${ }^{[16]}$. Magnetization curves of the composites were plotted from the data obtained from an AGGPAR 4500 vibrating sample magnetometer (VSM), calibrated against a cylindrical nickel standard at room temperature (cycle time $=1 \mathrm{~s}$ ) and hysteresis cycle time of $10 \mathrm{~min}^{[10-12]}$.

\section{Adsorption experiment}

The kinetics of phenol sorption was accomplished through batch mode experiments. The resins (1 g), previously swollen in ethanol $(24 \mathrm{~h})$, were put in contact with an aqueous solution of phenol $\left(30 \mathrm{mg} \mathrm{L}^{-1}, 50 \mathrm{~mL}\right)$ under continuous stirring (50 rpm), at $19{ }^{\circ} \mathrm{C}$, for various periods $(0,15,30,60,120$ and 150 minutes). The phenol concentrations in the solutions were measured using a UV spectrofluorometer (Varian, Cary Eclipse) at $294.92 \mathrm{~nm}$. All values in this work are the average of two independent experiments. The precision of the parallel measurements was $\mathrm{P}<0.0001$ using the Bartlett method. A calibration curve was plotted using phenol aqueous solutions at concentrations of $0,1,3,5,8,10,15,20,25$ and $30 \mathrm{mg} \mathrm{L}^{-1}$. The calibration curve was built using the regression technique with a correlation coefficient value not less than $0.99 .^{[8]}$. From these experiments, data were obtained on sorption capacity $\mathrm{q}_{\mathrm{e}}\left(\mathrm{mg} \mathrm{g}^{-1}\right)$ and amount of phenol adsorbed at time $\mathrm{t}_{\mathrm{t}}\left(\mathrm{mg} \mathrm{g}^{-1}\right)^{[3,7,17-19]}$. The kinetics of phenol sorption on the resins was analyzed using the following models: Lagergren pseudo first-order, Pseudo second-order, Elovich, Weber-Morris intraparticle diffusion and external diffusion ${ }^{[3,7,17-19]}$.

The adsorption data were analyzed in terms of Langmuir, Freundlich and Tempkin-Pyzhev isotherm models $^{[5,17,19,20]}$.

\section{Results and Discussion}

In this work, three PS-DVB copolymers were synthesized with different porosity characteristics, to assess the influence of the porosity of the supports on the phenol adsorption kinetics. These three copolymers were designated $\mathrm{C} 1, \mathrm{C} 2$ and $\mathrm{C} 3$, respectively, according to n-heptane/toluene ratios onto diluent mixture (90:10, 60:40 and 00:100 v/v).

As already observed by other studies, a rising concentration of $n$-heptane in the composition of diluent mixtures causes an increase in the porosity of the beads ${ }^{[21]}$ (Table 1). For copolymers $\mathrm{C} 1$ and $\mathrm{C} 3$, the increased content of $\mathrm{n}$-heptane in the porogenic mixture caused an increase in the specific area and pore volume, associated with a reduction of apparent density and swelling capacity in 1,2-dichloroethane. The data on specific area, pore volume and apparent density indicate that copolymers $\mathrm{C} 2$ and C3 have similar porosity degrees. 
Table 1. Morphological characteristics of Sty-DVB copolymers.

\begin{tabular}{ccccccccc}
\hline Copolymers & $\begin{array}{c}\text { Hep/Tol } \\
(\mathbf{V} / \mathbf{V})\end{array}$ & $\begin{array}{c}\mathbf{A} \\
\left(\mathbf{m}^{\mathbf{2}} \mathbf{g}^{-\mathbf{1}}\right)\end{array}$ & $\begin{array}{c}\mathbf{V}_{\mathbf{p}} \\
\left(\mathbf{c m}^{\mathbf{3}} \mathbf{g}^{-1}\right)\end{array}$ & $\begin{array}{c}\mathbf{d}_{\text {ap }} \\
\left(\mathbf{g ~ c m}^{\mathbf{3}}\right)\end{array}$ & $\begin{array}{c}\mathbf{I}_{\mathbf{D}} \\
(\boldsymbol{\%})\end{array}$ & $\begin{array}{c}\text { Sulphonated } \\
\mathbf{c o p o l y m e r s}\end{array}$ & $\begin{array}{c}\mathbf{I}_{\mathbf{w}} \\
(\boldsymbol{\%})\end{array}$ & $\begin{array}{c}\mathbf{C} \\
\left(\mathbf{m m o l g}^{-1}\right)\end{array}$ \\
\hline $\mathrm{C} 1$ & $90 / 10$ & 69.48 & 0.325 & 0.43 & 73 & $\mathrm{C} 1 \mathrm{~S}$ & 73 & 4.9 \\
$\mathrm{C} 2$ & $60 / 40$ & 1.48 & 0.0031 & 0.60 & 166 & $\mathrm{C} 2 \mathrm{~S}$ & 110 & 5.3 \\
$\mathrm{C} 3$ & $0 / 100$ & 1.53 & 0.0031 & 0.65 & 150 & $\mathrm{C} 3 \mathrm{~S}$ & 117 & 4.5 \\
\hline
\end{tabular}

Hep: $n$-heptane; Tol: toluene; $A$ : area; $V_{p}$ : pore volume; $d_{a p}$ : apparent density; $I_{D}$ : swelling degree in 1,2-dichloroethane; $I_{w}:$ swelling degree in water; $\mathrm{C}$ : ion exchange capacity (standard deviation $=2 \%, \mathrm{p}<0.0$ ).

The copolymers were sulfonated by reaction with acetyl sulfate, a weaker sulfonation agent than sulfuric acid. After the sulfonation reaction, the copolymers received the designation $\mathrm{C} 1 \mathrm{~S}, \mathrm{C} 2 \mathrm{~S}$ and $\mathrm{C} 3 \mathrm{~S}$. The occurrence of the sulfonation reaction can be evidenced by FTIR and EDS. After this reaction, it was possible to note the appearance of bands at $3428 \mathrm{~cm}^{-1}$, indicated as axial deformation of $\mathrm{O}-\mathrm{H}$ in the intermolecular hydrogen bond, in the range of 1300 to $1000 \mathrm{~cm}^{-1}$, due to the asymmetric and symmetric axial deformation of the $\mathrm{SO}_{2}$ group, and at $776 \mathrm{~cm}^{-1}$, caused by S-O stretching (Figure 1a). All the other sulfonated copolymers presented the same FTIR spectrum profile as that for $\mathrm{C} 1 \mathrm{~S}^{[22]}$. The presence of sulfonic groups can also be noted by an energy-dispersive $\mathrm{X}$-ray spectroscope (EDS) coupled to a scanning electron microscope. The presence of sulfur is confirmed by the appearance of a peak related to this element (Figure 1b). Besides this, the copolymers, previously hydrophobic, afterward presented capacity to swell in water due to the insertion of the $-\mathrm{SO}_{3} \mathrm{H}$ group in the polymer matrix (Table 1). The content of the accessible sulfonic groups can be assessed by determining the cation exchange capacity by acid-base titration.

The copolymer $\mathrm{C} 2$, with low specific surface area and immeasurable fixed pore volume, had a greater capacity to swell in 1,2-dichloroethane, which is considered a good solvent for PS-DVB copolymers according to the theory of solubility parameters of Hildebrand ${ }^{[23]}$. According to the data presented by Coutinho et al. ${ }^{[24]}$, the concentration of the sulfonic groups introduced in the polymer matrix increases in function of the capacity to swell in 1,2-dichloroethane. Therefore, we expected copolymers $\mathrm{C} 2$ and $\mathrm{C} 3$, with greater capacity to swell in 1,2-dichloroethane, to be sulfonated to a greater extent, and thus to present a greater cation exchange capacity. However, the data presented in Table 1 reveal that the cation exchange capacity did not vary significantly in function of the changing porosity degree of the copolymers.

The sulfonated copolymers (C1S, $\mathrm{C} 2 \mathrm{~S}$ and $\mathrm{C} 3 \mathrm{~S}$ ) were impregnated with $\mathrm{Ni}^{2+}$ and $\mathrm{Co}^{2+}$ ions by an ion exchange reaction with " $\mathrm{H}^{+}$" ions. Subsequently the ions $\mathrm{Ni}^{2+}$ and $\mathrm{Co}^{2+}$ were reduced to $\mathrm{Ni}^{0}$ and $\mathrm{Cu}^{0}$ by hydrazine under basic medium in order to introduce metal nanoparticles on this sulfonated polymeric matrix according to halfreactions ${ }^{[25,26]}$ :

$2 \mathrm{Ni}^{2+} / \mathrm{Co}^{2+}+\mathrm{N}_{2} \mathrm{H}_{4}+4 \mathrm{OH}^{-} \rightarrow 2 \mathrm{Ni}^{0} / \mathrm{Co}^{0}+\mathrm{N}_{2}+4 \mathrm{H}_{2} \mathrm{O}$

$\mathrm{N}_{2} \mathrm{H}_{4} \rightarrow \mathrm{N}_{2}+2 \mathrm{H}_{2}$

$3 \mathrm{~N}_{2} \mathrm{H}_{4} \rightarrow \mathrm{N}_{2}+4 \mathrm{NH}_{3}$
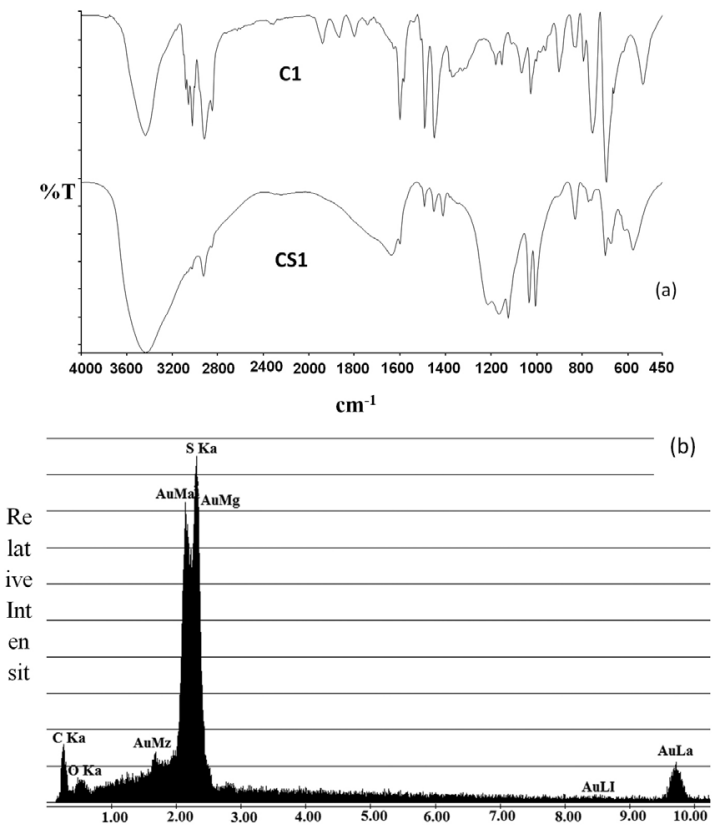

Figure 1. (a) FTIR spectra of the (PS-DVB) copolymers before (C1) and after (C1S) sulfonation, (b) X-ray energy dispersive analysis of the external surface of sulfonated resins (C2S).

These oxidation-reduction reactions were carried out in presence of polyvinylpyrrolidone employed as colloid protector, aiming to reduce the agglutination of the metal particles $^{[25]}$. In this process, six polymeric composites designated $\mathrm{C} 1 \mathrm{SNi}, \mathrm{C} 1 \mathrm{SCo}, \mathrm{C} 2 \mathrm{SNi}, \mathrm{C} 2 \mathrm{SCo}, \mathrm{C} 3 \mathrm{SNi}$ and $\mathrm{C} 3 \mathrm{SCo}$ were prepared. Figure 2 presents scanning electron micrographs of the composites $\mathrm{C} 3 \mathrm{SNi}, \mathrm{C} 1 \mathrm{SCo}$, C3SCo, EDS spectra of the composites $\mathrm{C} 2 \mathrm{SNi}$ and $\mathrm{C} 2 \mathrm{SCo}$ and hysteresis curves for the resins impregnated with cobalt.

The composites derived from the sulfonated copolymers C1S and C3S presented the same EDS spectrum profile as those derived from the copolymer $\mathrm{C} 2 \mathrm{~S}$. The nickel particles formed agglomerates all along the surface of the composite C3SNi (Figure 2a). In contrast, the cobalt particles only formed agglomerates at preferential points of the surface of composite C1SCo (Figure 2b). It is possible that in these cases coalescence occurred and the PVP content was not sufficient to protect the metal particles, impeding their agglutination on the surface of the sulfonated copolymers $\mathrm{C} 3$ and $\mathrm{C} 1{ }^{[27,28]}$. This behavior indicates that the porosity did not have an influence on the coalescence phenomenon, which can be related to the poly(vinyl pyrrolidone) content being insufficient to protect the metal particles. 


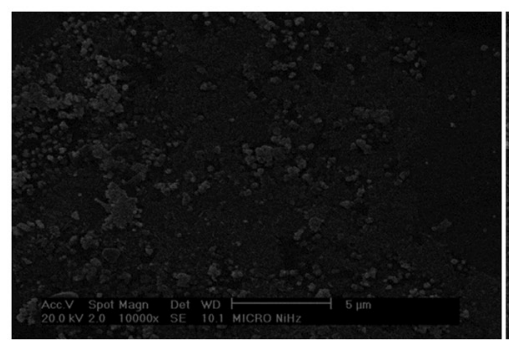

(a)

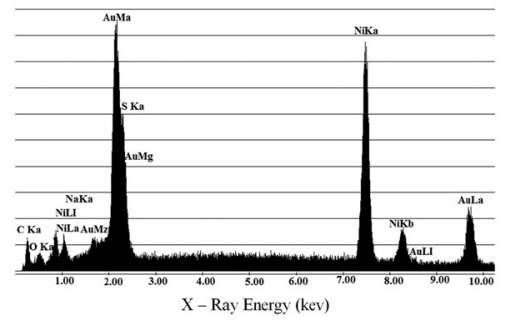

(d)

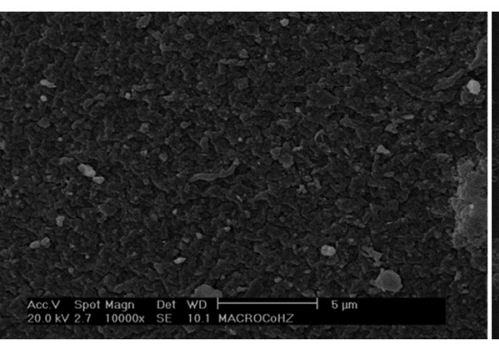

(b)

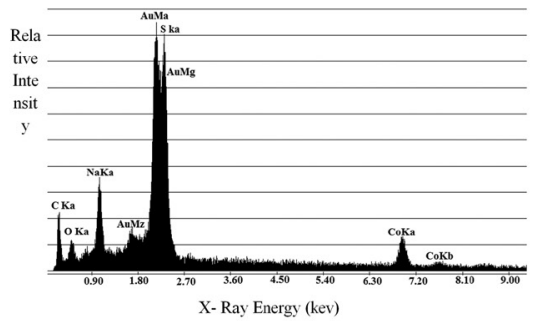

(e)

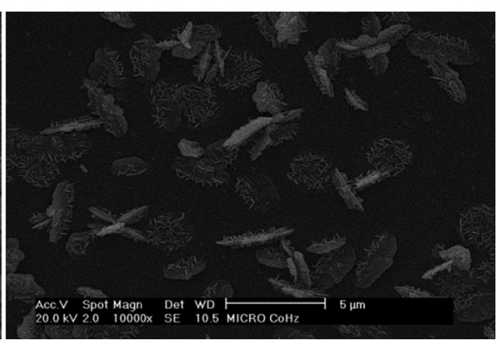

(c)

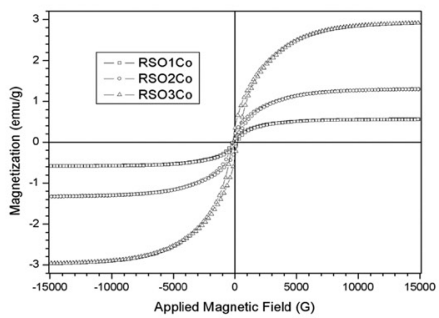

(f)

Figure 2. Scanning electron micrographs of composites: C3SNi (a), C1SCo (b), C3SCo (c). X-ray energy dispersive analysis of the external surface of composites: $\mathrm{C} 2 \mathrm{SNi}(\mathrm{d})$ and $\mathrm{C} 2 \mathrm{SCo}(\mathrm{e})$. Hystereses loops and room temperature magnetization curves as a function of applied magnetic field strength for the composite samples anchored with Co (f).

The composite C3SCo (Figure 2c) presented cobalt crystals with dendritic morphology due to the orientation of the crystals. This morphology can be due to various factors, such as temperature, type of solvent and viscosity of the solvent ${ }^{[29]}$. Analysis of the energy-dispersive X-ray spectra (Figures $2 \mathrm{~d}, \mathrm{e}$ ) confirmed the presence of metals on the external surface of the beads.

The magnetic parameters of the composites containing Ni particles were: $\mathrm{H}_{\mathrm{c}}$ (Gauss): 217.74, 295.60 and 148.34, $\mathrm{M}_{\mathrm{s}}\left(\mathrm{emu} \mathrm{g}^{-1}\right): 1.3381,1.5081$ and 2.7952, $\mathrm{M}_{\mathrm{r}}\left(\mathrm{emu} \mathrm{g} \mathrm{g}^{-1}\right): 0.18469,0.56403$ and 0.52129 . For the composites containing Co particles the values of magnetic parameters were: $\mathrm{H}_{c}$ (Gauss): 181.08, 213.95 and 209.26, $\mathrm{M}_{\mathrm{s}}\left(\mathrm{emu} \mathrm{g}^{-1}\right): 0.57398,1.3133$ and 2.9383, $\mathrm{M}_{\mathrm{r}}\left(\mathrm{emu} \mathrm{g}^{-1}\right)$ : $0.07767,0.19034,0.36162$.

The composite C1SCo has supermagnetic behavior, indicating that each particle acts as a single magnetic domain without hysteresis ${ }^{[10-14]}$. In contrast the composites $\mathrm{C} 2 \mathrm{SCo}$ and $\mathrm{C} 3 \mathrm{SCo}$ have smooth hysteresis, presenting the behavior of ferromagnetic materials (Figure 2f). Since the hysteresis of the materials synthesized in this work has a very small coercitive field, it can be said that these materials have soft magnetic behavior.

The remanent magnetization $\left(\mathrm{M}_{\mathrm{r}}\right)$ and saturation magnetization results are near zero for the composite C1SCo confirming the supermagnetic behavior of this material ${ }^{[10-14]}$. There was a tendency for the magnetic parameters $M_{s}$ and $M_{r}$ of the composites to increase with greater swelling capacity of the sulfonic resins in water (Table 1). This swelling capacity declined linearly in function of the increase in porosity of the precursor copolymers. The sulfonic resins were previously swollen in aqueous solutions of nickel and cobalt salts before the reaction with hydrazine. Probably the materials with greater swelling capacity in water offered a larger contact surface for the reduction reaction and generated composites containing agglomerates of particles distributed more homogeneously on the surface of the beads.

All the polymers synthesized in this work were assessed in batch experiments for their capacity to adsorb phenol from aqueous solutions. The copolymer C1 (unmodified) presented a higher phenol adsorption capacity than copolymers $\mathrm{C} 2$ and $\mathrm{C} 3$ (Figure $3 \mathrm{a}$ ). This can be explained by the greater porosity of the first copolymer, which permits the diffusion of phenol molecules inside the beads. After the sulfonation reaction, copolymers $\mathrm{C} 2$ and $C 3$ presented higher $q_{e}$ values than the unmodified copolymers (Figure $2 \mathrm{~b}$ ). This can be related to the greater swelling capacity of these materials in water (Table 1). In general, the composites derived from copolymer $\mathrm{C} 1$ showed greater capacity to adsorb phenol. The phenol adsorption capacity of composite C1SNi was around $90 \%$ (Figure 3a), which can be related to the better distribution of the nickel particles on the surface of the sulfonated copolymer C1S (Figure 2a). The experimental $\mathrm{q}_{\mathrm{e}}$ value obtained for this material $\left(1.299 \mathrm{mg} \mathrm{g}^{-1}\right)$ is similar to the theoretical value of $\mathrm{q}_{\mathrm{e}}\left(1.326 \mathrm{mg} \mathrm{g}^{-1}\right)$.

The removal kinetics tests were carried out by employing contact times of $0,15,30,60,120$ and 150 minutes. Figure $3 \mathrm{c}$ shows the phenol adsorption kinetics curves of the composites impregnated with nickel and cobalt while Figure 3d presents the data on the quantity of phenol molecules adsorbed in function of time $\left(q_{t}\right)$ for these materials.

The majority of the materials impregnated with nickel and cobalt showed a tendency for increased phenol adsorption after 60 minutes of contact between the composite and the solution. This result can be explained by the fact that phenol is adsorbed by a multi-layer process. After a determined contact time, the phenol molecules present in the internal structure of the resin favor the diffusion of new molecules, which causes an increase in $\mathrm{q}_{\mathrm{t}}$ (capacity to adsorb phenol in contact time 


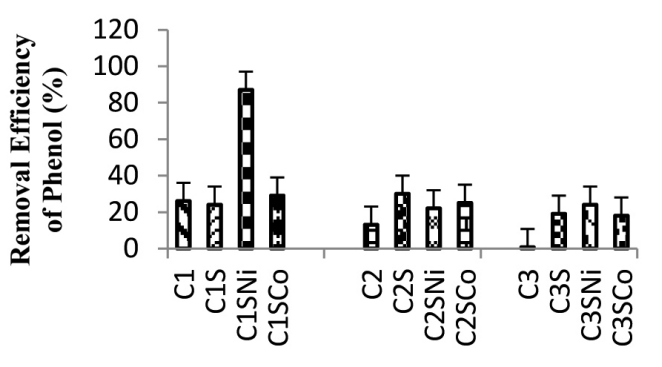

Materials

(a)

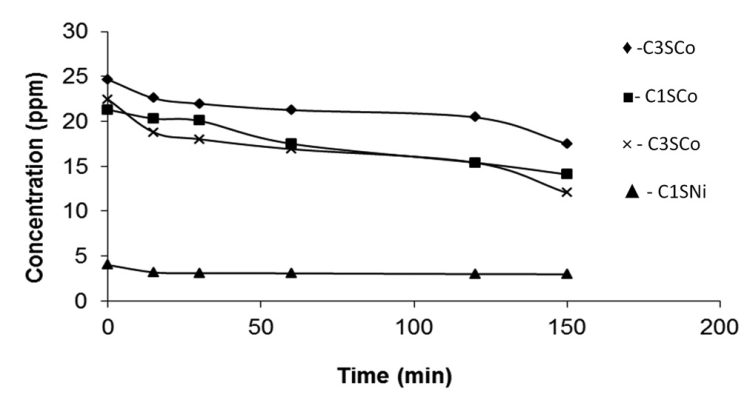

(c)

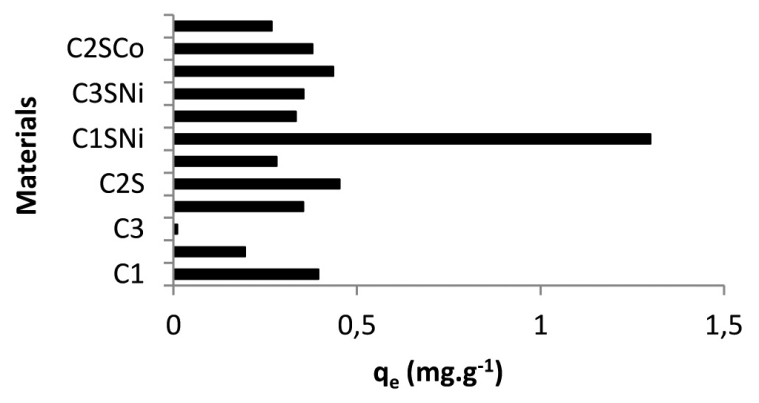

(b)

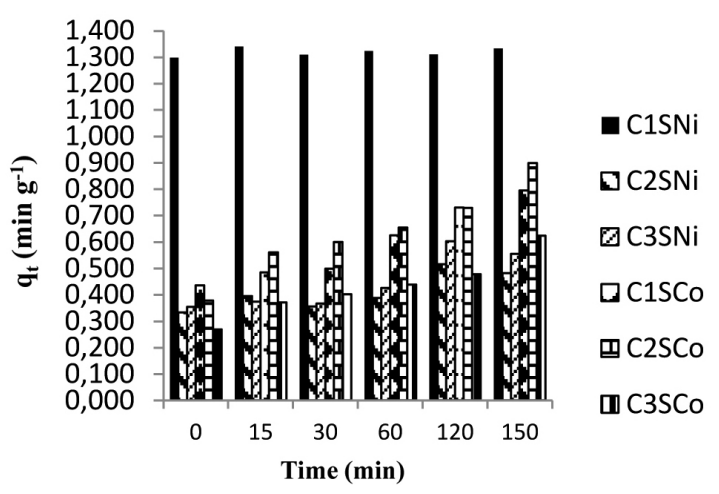

(d)

Figure 3. Removal efficiency (a), sorption capacity qe (b), adsorption kinetics curves of phenol (c) and amount of phenol adsorbed at time t $\mathrm{q}_{\mathrm{t}}\left(\mathrm{mg} \mathrm{g}^{-1}\right)$ (d) for the composites C1SNi, C2SNi, C3SNi, C1SCo, C2SCo and C3SCo.

t). For the composite $\mathrm{C} 1 \mathrm{SNi}$, the phenol adsorption equilibrium was reached more quickly, after 15 minutes of contact, which can be due to the greater porosity of the precursor copolymer of this composite and the distribution of nickel on the beads surface. It is probable that for this material, the formation of the phenol layers inside the polymer particles occurs faster, favoring better phenol adsorption kinetics.

To investigate the phenol adsorption mechanism, the Lagergren pseudo first-order, pseudo second-order, Elovick, diffusion-based external diffusion, Weber-Morris intraparticle diffusion and pore and surface mass diffusion models were fitted to the phenol adsorption kinetics data of the composite C1SNi (Table 2). This knowledge is essential to understand the sorption process and plan the most suitable strategy for the desorption process ${ }^{[17-19]}$.

The pseudo first-order kinetics model proposed by Lagergren is the first kinetics equation that relates adsorption in solid-liquid systems with the sorption capacity of the solid, $\mathrm{q}_{\mathrm{e}}^{[17-19,30]}$. According to this kinetics model, only the characteristics of the sorbent influences the adsorption kinetics, while the variation of the medium characteristics such as initial concentration of ions, $\mathrm{pH}$, temperature, time, do not influence the adsorption mechanism. The correlation coefficient $\left(\mathrm{R}^{2}\right)$ found by applying the Lagergren equation was small, indicating that the plot of $\log \left(\mathrm{q}_{\mathrm{e}}-\mathrm{q}_{\mathrm{t}}\right)$ versus $t$ was not linear. It is possible to observe a significant difference between the theoretical and experimental $\mathrm{q}_{\mathrm{e}}$ data. This shows that the Lagergren
Table 2. Kinetic parameters for the composite C1SNi.

\begin{tabular}{|c|c|c|}
\hline Kinetic Models & Coefficients & Data \\
\hline \multirow[t]{4}{*}{ Pseudo first-order } & $\mathrm{q}_{\mathrm{e}}, \exp \left(\mathrm{mg} \mathrm{g}^{-1}\right)$ & 1.299 \\
\hline & $\mathrm{q}_{\mathrm{e}}, \mathrm{t}\left(\mathrm{mg} \mathrm{g}^{-1}\right)$ & 0.368 \\
\hline & $\mathrm{K}_{1}\left(\mathrm{~L} \mathrm{~g}^{-1}\right)$ & $3.0 \times 10^{-5}$ \\
\hline & $\mathrm{R}^{2}$ & $1.0 \times 10^{-5}$ \\
\hline \multirow[t]{4}{*}{ Pseudo second-order } & $\mathrm{q}_{\mathrm{e}}, \exp \left(\mathrm{mg} \mathrm{g}^{-1}\right)$ & 1.299 \\
\hline & $\mathrm{q}_{\mathrm{e}},{ }_{\mathrm{t}}\left(\mathrm{mg} \mathrm{g}^{-1}\right)$ & 1.326 \\
\hline & $\mathrm{K}_{2}\left(\mathrm{~g} \mathrm{mg}^{-1} \min ^{-1}\right)$ & 4.587 \\
\hline & $\mathrm{R}^{2}$ & 0.999 \\
\hline \multirow[t]{5}{*}{ Elovick } & $\mathrm{q}_{\mathrm{e}}, \exp \left(\mathrm{mg} \mathrm{g}^{-1}\right)$ & 1.299 \\
\hline & $\mathrm{q}_{\mathrm{e}},{ }_{\mathrm{t}}\left(\mathrm{mg} \mathrm{g}^{-1}\right)$ & $9.2 \times 10^{-3}$ \\
\hline & $\alpha\left(\mathrm{mg} \mathrm{g}^{-1} \mathrm{~min}^{-1}\right)$ & 3.807 \\
\hline & $\beta\left(\mathrm{mg} \mathrm{g}^{-1} \mathrm{~min}^{-1}\right)$ & 294 \\
\hline & $\mathrm{R}^{2}$ & 0.059 \\
\hline \multirow{2}{*}{$\begin{array}{l}\text { Diffusion-based } \\
\text { external diffusion }\end{array}$} & $\mathrm{K}_{\mathrm{f}}\left(\mathrm{cm} \mathrm{s}^{-1}\right)$ & 0.0031 \\
\hline & $\mathrm{R}^{2}$ & 0.077 \\
\hline \multirow{2}{*}{$\begin{array}{l}\text { Weber-Morris intra- } \\
\text { particle diffusion }\end{array}$} & $\mathrm{K}_{\mathrm{id}}\left(\mathrm{mg} \mathrm{g}^{-1} \min ^{1 / 2}\right)$ & $1.3 \times 10^{-3}$ \\
\hline & $\mathrm{R}^{2}$ & 0.1508 \\
\hline \multirow{2}{*}{$\begin{array}{l}\text { Pore and surface } \\
\text { mass diffusion }\end{array}$} & $\mathrm{D}\left(\mathrm{cm}^{2} \mathrm{~s}^{-1}\right)$ & $2,1 \times 10^{-9}$ \\
\hline & $\mathrm{R}^{2}$ & $5.0 \times 10^{-6}$ \\
\hline
\end{tabular}

$\mathrm{q}_{\mathrm{e}}$, exp.: experimental sorption capacity $\left(\mathrm{mg} \mathrm{g}^{-1}\right) ; \mathrm{q}_{\mathrm{e}}$, t: theorical sorption capacity $\left(\mathrm{mg} \mathrm{g}^{-1}\right) ; \mathrm{K}_{1}$ : pseudo-first order rate constant $\left(\mathrm{L} \mathrm{g}^{-1}\right) ; \mathrm{R}^{2}$ : correlation coefficient; $\mathrm{K}_{2}$ : pseudo-second order rate constant $\left(\mathrm{g} \mathrm{mg}^{-1} \mathrm{~min}^{-1}\right) ; \alpha$ : initial adsorption rate $\left(\mathrm{mg} \mathrm{g}^{-1} \mathrm{~min}^{-1}\right) ; \beta$ : desorption constant $\left(\mathrm{mg} \mathrm{g}^{-1} \mathrm{~min}^{-1}\right)$; Kf: initial external mass transfer coefficient $\left(\mathrm{cm} \mathrm{s}^{-1}\right)$; kid: intra-particle diffusion rate constant $\left(\mathrm{mg} \mathrm{g}^{-1} \mathrm{~min}^{-1 / 2}\right)$; D: mean particle diameter of ion-exchanger $(\mathrm{cm})$. 
Table 3. Parameters of the adsorption models Langmuir, Freundlich and Tempkin from composite C1SNi.

\begin{tabular}{|c|c|c|c|c|c|c|c|c|}
\hline \multicolumn{3}{|c|}{ Langmuir } & \multicolumn{3}{|c|}{ Freundlich } & \multicolumn{3}{|c|}{ Tempkin } \\
\hline $\mathbf{Q}^{0}$ & $\begin{array}{c}\mathbf{b} \\
\left(\mathbf{L} \cdot \mathrm{g}^{-1}\right) \\
\end{array}$ & $\mathbf{r}^{2}$ & $1 / n$ & $\begin{array}{c}\mathbf{K}_{\mathrm{f}} \\
\left(\mathrm{mg} \cdot \mathrm{g}^{-1}\right)\end{array}$ & $\mathbf{r}^{2}$ & $\mathbf{b}_{\mathrm{T}}$ & A & $\mathbf{r}^{2}$ \\
\hline 1.161 & 2.32 & 0.9999 & 0.131 & 1.57 & 0.9048 & 10770 & 1.96 & 0.8802 \\
\hline
\end{tabular}

$\mathrm{Q}^{0}$ : Langmuir constant related to monolayer capacity $\left(\mathrm{mg} \mathrm{g}^{-1}\right)$; b: Langmuir constant related to the free energy of adsorption $\left(\mathrm{dm}^{3} \mathrm{~g}^{-1}\right) ; 1 / \mathrm{n}$ : heterogeneity factor; $\mathrm{k}_{\mathrm{f}}$ : Freundlich constant $\left(\mathrm{mg} \mathrm{g}^{-1}\right) ; \mathrm{b}_{\mathrm{T}}$ : Tempkin constant related to heat of sorption $\left(\mathrm{J} \mathrm{mol}^{-1}\right)$; R: gas constant $\left(8.314 \mathrm{~J}\right.$ mol $^{-1}$ $\mathrm{K})$; T: temperature $(\mathrm{K})$; A: Tempkin isotherm constant related to adsorbate/adsorbate interaction $\left(\mathrm{L} \mathrm{g}^{-1}\right)$.

model is not applicable to describe the adsorption kinetics mechanism of phenol for the composite C1SNi. This behavior has also been observed in other works ${ }^{[31]}$.

The pseudo second-order kinetics model assumes that the chemisorption process is part of the step that determines the adsorption rate ${ }^{[30]}$. The high correlation coefficient obtained by applying the pseudo second-order equation demonstrates that this is the most suitable model to describe the adsorption kinetics behavior of phenol by the composite C1SNi. The experimental value of $q_{e}$ is near the value obtained by applying the pseudo second-order equation. These results indicate that the rate of phenol adsorption by this composite depends on the chemical interaction between the adsorbent and the adsorbate.

The Elovich equation is commonly employed to determine the chemisorption kinetics of gases by heterogeneous adsorbents $\mathrm{s}^{[17-19,30,31]}$. The correlation coefficient obtained was only 0.059 , indicating that this model is not adequate to describe the phenol adsorption kinetics in aqueous solution by the magnetic composite.

The correlation coefficient values obtained by applying the diffusion-based external diffusion, WeberMorris intraparticle diffusion and pore and surface mass diffusion models also were very low, demonstrating that these models are not suitable to describe the kinetics behavior. This indicates that the solute transfer process between the resin phase and the solution does not influence the adsorption speed ${ }^{[17-19,30,31]}$.

In order to determine the most adequate isotherm model that describes the adsorption process of phenol for the composite C1SNi the adsorption data, it was evaluated the Langmuir, Freundlich and Tempkin-Pyzhev models $s^{[5,17,19,20]}$. The calculated constants for these adsorption models are presented on Table 3 .

The higher $\mathrm{r}^{2}$ value obtained from the Langmuir model reveals that the sorption process of phenol by the composite $\mathrm{C} 1 \mathrm{SNi}$ is better descripted by this model, i.e. the phenol molecules are adsorbed in monolayer form on specific well-defined sites located on the surface of the composite $\mathrm{C} 1 \mathrm{SNi}^{\left[{ }^{[32]}\right.}$. In contrast to the Freundlich, the Langmuir model assumes a homogeneous energetic distribution of the active binding sites on the adsorbent surface $^{[20,32]}$. Thus we can to assume a homogeneous distribution of nickel particles on surface of the composite $\mathrm{C} 1 \mathrm{SNi}$, as already observed to the composite C3SNi (MEV presented on Figure 2a) which made possible a homogeneous adsorption of the phenol molecules for this material.

We observed that the Tempkin model is not explored on many works that to study the process of phenol adsorption by polymeric crosslinked resins ${ }^{[1,5,6,33,34]}$. According to this model, it was observed that the heat of sorption of all molecules in the layer decreased linearly in function of the coverage process ${ }^{[35]}$. The low $\mathrm{r}^{2}$ value calculated by applying this model suggests that it is not adequate to describe the phenol adsorption by the $\mathrm{C} 1 \mathrm{SNi}$ composite.

Comparing the value of Langmuir constant related to monolayer capacity (Q0) calculated in this work with other values of Q0 obtained for polymeric resins ${ }^{[1,5,6,33,34]}$, it is possible to affirm that the composite $\mathrm{C} 1 \mathrm{SNi}$ presented a good phenol adsorption capacity.

\section{Conclusions}

Three sulfonated Sty-DVB resins, differing in porous characteristics, were used to obtain composites with magnetic properties after incorporating metallic ions $(\mathrm{Ni}$ or Co).The phenol adsorption capacity of the unmodified copolymers, sulfonic resins and composites was related to their swelling capacity in water, porosity and content of active groups. For the metallic composites, besides the porosity of the precursor copolymers, there seems to be a strong influence of the homogeneity distribution of the metal in the polymeric matrix. Composite C1SNi achieve phenol removal efficiency around 90\%. The phenol adsorption kinetics is also influenced by the polymer porosity and metal distribution: higher porosity of the polymeric matrix associated with a more homogenous distribution of the metal provides increasing adsorption kinetics. The pseudo second-order equation fitted the phenol adsorption kinetics data well. The other kinetics models exhibited a poor correlation. This indicates that the rate of phenol adsorption by this composite depends on the chemical interaction between the adsorbent and the adsorbate. The Langmuir model describes successfully the phenol removal by the composite C1SNi.

\section{Acknowledgements}

We thank the Conselho Nacional de Desenvolvimento Científico e Tecnológico (CNPq), Fundação Coordenação de Aperfeiçoamento de Pessoal de Nível Superior (CAPES) and Fundação de Amparo à Pesquisa do Estado do Rio de Janeiro (FAPERJ) for financial support. We would also like to express thanks to Petroflex, Nitriflex and Metacril for donating the monomers and initiators.

\section{References}

1. Caetano, M.; Valderrama, C.; Farran, A. \& Cortina, J. L. - J. Coll. Interf. Sci., 338, p.402 (2009). PMid:19679317. http://dx.doi.org/10.1016/j.jcis.2009.06.062

2. Zhang, W.; Chen, J.; Pan, B.; Chen, Q.; He, M.; Zhang, Q.; Wang, F. \& Zhang, B. - React. Funct. 
Polym., 66, p.395 (2006). http://dx.doi.org/10.1016/j. reactfunctpolym.2005.08.016

3. Lin, S.-H. \& Juang, R.-S. - J. Environm. Manag., 90, p.1336 (2009). PMid:18995949. http://dx.doi.org/10.1016/j. jenvman.2008.09.003

4. Zhang, W. M.; Chen, J. L.; Pan, B. C.; Zhang, Q. X. \& Zhang, B. - J. Haz. Mat., 128, p.123 (2006). PMid:16457950. http://dx.doi.org/10.1016/j.jhazmat.2005.03.036

5. Zeng, X.; Yu, T.; Wang, P.; Yuan, R.; Wen, Q.; Fan, Y.; Wang, C. \& Shi, R. - J. Haz. Mat., 177, p.773 (2010). PMid:20083347. http://dx.doi.org/10.1016/j. jhazmat.2009.12.100

6. Fan, J.; Yang, W. \& Li, A. - React. Funct. Polym., 71, p.994 (2011). http://dx.doi.org/10.1016/j. reactfunctpolym.2011.07.001

7. Kawabata, N.; Tsuchida, Y.; Nakamori, Y. \& Kitamura, M. - React. Funct. Polym., 66, p.1641 (2006). http://dx.doi. org/10.1016/j.reactfunctpolym.2006.06.008

8. Queirós, Y. G. C. - “Avaliação de resinas poliméricas no processo de purificação de água contaminada com componentes aromáticos", Tese de Doutorado, Universidade Federal do Rio de Janeiro, Brasil (2006).

9. Louvisse, A. M. T.; Lucas, E. F.; Barbosa, L. C. F.; Clarisse, M. D. \& Queirós, Y. G. C. - "Método de remoção de óleo e graxa em água por adsorção em resina polimérica”, BR Patent PI0803656-0A2 (2008). Disponível em: <www. patentesonline.com.br>.

10. Santa Maria, L. C.; Simplício, S.; Ribeiro, C. A. B.; Costa, M. A. S.; Silva, M. R.; Hui, W. S. \& Amico, S. C. - Polym. Eng. Sci., 48, p.1878 (2008)

11. Santa Maria, L. C.; Costa, M. A. S.; Soares, J. G. M.; Wang, S. H. \& Silva, M. R. - Polymer, 46, p.11288 (2005). http:// dx.doi.org/10.1016/j.polymer.2005.09.055

12. Conceição, B. M. da; Costa, M. A. S.; Santa Maria, L. C. de; Silva, M. R. \& Wang, S. H. - Polímeros, 21, p.409 (2011). http://dx.doi.org/10.1590/S0104-14282011005000070

13. Costa, C. N.; Costa, M. A.S.; Santa Maria, L. C.; Silva, M. R.; Souza Junior, F. G. \& Michel, R. C. - Polímeros, 22, p.260 (2012). http://dx.doi.org/10.1590/S010414282012005000042

14. Castanharo, J. A.; Mello, I. L.; Santa Maria, L. C.; Costa, M. A. S.; Silva, M. R. \& Oliveira, M. G. - Polímeros, 22, p.303 (2012). http://dx.doi.org/10.1590/S010414282012005000038

15. Oliveira, A. J. B.; Aguiar, A. P.; Marques, M. R. C. \& Santa Maria, L. C. - Mat. Let., 59, p.1089 (2005).

16. Helfferich, F. G. - "Ion Exchange", chap. 4, Dover Publications, New York (1995). PMid:7756766.

17. Dizge, N.; Keskinler, B. \& Barlas, H. - J. Haz. Mat., 167, p.915 (2009). PMid:19231079. http://dx.doi.org/10.1016/j. jhazmat.2009.01.073

18. Huang, J.; Deng, R. \& Huang, K. - Chem. Eng. J., 171, p.951 (2011). http://dx.doi.org/10.1016/j.cej.2011.04.045
19. Yin, J.; Chen, R.; Ji, Y.; Zhao, C.; Zhao, G. \& Zhang, H. - Chem. Eng. J., 157, p.466 (2010). http://dx.doi. org/10.1016/j.cej.2009.12.008

20. Dotto, G. L.; Vieira, M. L. G. Gonçalves, J. O. \& Pinto, L. A. A. - Quím. Nova, 34, p.1193 (2011). http://dx.doi. org/10.1590/S0100-40422011000700017

21. Costa, L. C.; Gomes, A. S.; Coutinho, F. M. B. \& Teixeira, V. G. - React. Funct. Polym., 70, p.738 (2010). http:// dx.doi.org/10.1016/j.reactfunctpolym.2010.07.003

22. Silverstain, R. M.; Webster, F. X. \& Kiemle, D. J. - "Spectrometric Identification of Organic Compounds", LTC, New York (2007).

23. Barton, A. F. M. - "Handbook of polymer-liquid interactions parameters and solubility parameters", CRC Press, Boston (1990).

24. Coutinho, F. M. B.; Souza, R. R. \& Gomes, A. S. - Eur. Polym. J., 40, p.1525 (2002). http://dx.doi.org/10.1016/j. eurpolymj.2004.02.003

25. Cushing, B.L.; Kolesnichenko, V. L. \& O'Connor, C. J. - Chem. Rev., 104, p.3893 (2004). PMid:15352782. http://dx.doi.org/10.1021/cr030027b

26. Li, Z.; Han, C. \& Shen, J. - J. Mater. Sci., 41, p.3473 (2006). http://dx.doi.org/10.1007/s10853-005-5874-z

27. Couto, G. G. - "Nanopartículas de níquel: síntese, caracterização, propriedades e estudo de sua utilização como catalisadores na obtenção de nanotubos de carbono”, Dissertação de Mestrado, Universidade Federal do Paraná, Brasil (2006).

28. Scheeren, C. W. - "Líquidos iônicos aplicados na síntese e estabilização de nanopartículas de Pt (0) e Pd/Pt (0), caracterização e estudos em reações de hidrogenação catalítica", Tese de Doutorado, Universidade Federal do Rio Grande do Sul, Brasil (2006).

29. Zhu, Y.; Zheng, H.; Yang, Q.; Pan, A.; Yang, Z. \& Qian, Y. - J. Cryst. Growth, 260, p.427 (2004). http://dx.doi. org/10.1016/j.jcrysgro.2003.08.037

30. Ho Y-S. - J. Haz. Mat., 136, p.681 (2006).

31. Wolowicz, A. \& Hubicki, Z. - Chem. Eng. J., 171, p.206 (2011).

32. Kołodynska, D. - Desalination, 263, p.159 (2010).

33. Zeng, X.; Fan, Y.; Wu, G.; Wang, C. \& Shi, R. - J. Haz. Mat., 169, p.1022 (2009). PMid:19443106. http://dx.doi. org/10.1016/j.jhazmat.2009.04.044

34. Jin, X.; Li, Y.; Yu, C.; Ma, Y.; Yang, L. \& Hu, H. - J. Haz. Mat., 198, p.247 (2011). PMid:22047723. http://dx.doi. org/10.1016/j.jhazmat.2011.10.040

35. Wolowicz, A. \& Hubicki, Z. - Chem. Eng. J., 160, p.660 (2010).

Received: 03/13/13

Revised: 06/06/13

Accepted: 07/10/13 